\title{
A search for tyrosine kinase receptors expressed in the rat embryonic pancreas
}

\author{
S. LeBras, P. Czernichow, R. Scharfmann \\ INSERM U457 Hospital R. Debré, Paris, France
}

\begin{abstract}
Summary It is known that during embryonic life, interactions between the pancreatic epithelium and its surrounding mesenchyme are important for proper development of the pancreas. These interactions are thought to be mediated by soluble factors, which could be, as in other tissues, the ligands of tyrosine kinase receptors. In this study, we screened for tyrosine kinase receptors expressed in pancreata of 13-dayold embryonic rats. Using a polymerase chain reaction-based approach that exploits sequence similarities within the catalytic kinase domains of these receptors, we identified 30 different tyrosine kinase receptors. The same approach was then used on cDNA prepared from fractions enriched in epithelium or in mesenchyme. Receptors for factors such as platelet derived growth factors were found to be expressed
\end{abstract}

both in the epithelial and the mesenchymal fractions. Receptors for stem cell factor, for epidermal growth factor family members were mainly found in the epithelial fraction. The profile of expression of receptor tyrosine kinases in the embryonic pancreas was finally compared to the one found in other tissues and cell types, such as kidney, brain or INS-1 cells. Platelet derived growth factor receptors and ErbB2 were found to be enriched in the embryonic pancreas when compared with other tissues. It will now be possible to test the effects of the ligands of the different receptors we have cloned, on the differentiation and growth of the pancreas. [Diabetologia (1998) 41: 1474-1481]

Keywords Pancreas, development, epithelium, mesenchyme, receptor tyrosine kinases.
The pancreas, like the kidney, lung, and mammary gland belong to a class of organs composed of an epithelium and a mesenchyme. In these organs, it is thought that interactions between the epithelium and the mesenchyme are necessary for proper development. A large number of these interactions are me-

Received: 22 May 1998 and in revised form: 10 July 1998

Corresponding author: R. Scharfmann, INSERM U457 Hospital R. Debré, 48 Bd Serurier 75019 Paris, France

Abbreviations: E0, Embryonic day 0; E13, embryonic day 13; PCR, polymerase chain reaction; RT, reverse transcriptase; PDGFR, platelet derived growth factor receptor; EGFR, epidermal growth factor receptor; FGFR, fibroblast growth factor receptor; IGF1R, insulin-like growth factor receptor; FAK, focal adhesion kinase; INSR, insulin receptor; HGFR, hepatocyte growth factor receptor; HB-EGF, heparin binding epidermal growth factor-like growth factor. diated by soluble factors which are frequently ligands of tyrosine kinase receptors [1-3].

It is well established that during embryonic life, the development of the pancreatic epithelium is controlled by signals derived from the mesenchyme [4-6]. These effects are mediated, at least in part, by soluble factors [5,6]. Although attempts have been made to characterize such factors, their exact nature is not known [7]. Because ligands of tyrosine kinase receptors are implicated in interactions between the mesenchyme and epithelium in other tissues, we postulated that such an interaction could also be important for proper development of the pancreas. We screened for tyrosine kinase receptors expressed in the rat embryonic pancreas with an approach that exploits sequence similarities within the catalytic kinase domains of these receptors [8]. We identified 30 different tyrosine kinase receptors in embryonic day 13 (E13) pancreata and further confirmed the expres- 
Table 1. PCR primers used for amplification of protein tyrosine kinases

\begin{tabular}{|c|c|c|}
\hline Primer & Sequence $5^{\prime}-3^{\prime}$ & PCR product size \\
\hline $\begin{array}{l}\text { PDGFR } \alpha-5^{\prime}-886 \\
\operatorname{PDGFR} \alpha-3^{\prime}-1145\end{array}$ & $\begin{array}{l}\text { GGAGAGGTGAGAAACAAAGGCAT } \\
\text { ACCACGAACTCTCTGACCTGATG }\end{array}$ & $262 \mathrm{bp}$ \\
\hline $\begin{array}{l}\text { PDGFR } \beta-5^{\prime}-865 \\
\text { PDGFR } \beta-3^{\prime}-1165\end{array}$ & $\begin{array}{l}\text { AGACGTACAAATTGCTGAGCTGC } \\
\text { ACTCAGCTCCAGTACACGGACAG }\end{array}$ & $303 \mathrm{bp}$ \\
\hline $\begin{array}{l}\text { FLT1-5'-446 } \\
\text { FLT1-3'-808 }\end{array}$ & $\begin{array}{l}\text { GGACAAAAAGCTGAGCGTCACTA } \\
\text { CCTCTCCTACTGTCCCACGCTAT }\end{array}$ & $365 \mathrm{bp}$ \\
\hline $\begin{array}{l}\text { c-kit-5'-887 } \\
\text { c-kit-3'-1230 }\end{array}$ & $\begin{array}{l}\text { AGCAAGAGTTAACGATTCCGGAG } \\
\text { CCAGAAAGGTGTAAGTGCCTCCT }\end{array}$ & $346 \mathrm{bp}$ \\
\hline $\begin{array}{l}\text { EGFR-5'-43 } \\
\text { EGFR-3'-375 }\end{array}$ & $\begin{array}{l}\text { AAACTTGGAAATCACCTATGTGCAA } \\
\text { CTCAGAAAGACATCTTGGACGATGT }\end{array}$ & $333 \mathrm{bp}$ \\
\hline $\begin{array}{l}\text { erbB2- }-5^{\prime}-200 \\
\text { erbB2-3'-578 }\end{array}$ & $\begin{array}{l}\text { AACTTGGAGCTTACCTACGTGCC } \\
\text { TATCGACAGGAGCCAGTTGGTTA }\end{array}$ & $381 \mathrm{bp}$ \\
\hline $\begin{array}{l}\text { FGFR1-5' }-573 \\
\text { FGFR1-3'-924 }\end{array}$ & $\begin{array}{l}\text { GAAAAACGGCAAGGAATTCAAAC } \\
\text { GTCATACGGCAAGTTGTCTGGAC }\end{array}$ & $352 \mathrm{bp}$ \\
\hline $\begin{array}{l}\text { FGFR2 IIIb-5'-2 } \\
\text { FGFR2 IIIb-3'-281 }\end{array}$ & $\begin{array}{l}\text { GAGCACCGTACTGGACCAACAC } \\
\text { TGGTAGGTGTGGTTGATGGACC }\end{array}$ & $280 \mathrm{bp}$ \\
\hline $\begin{array}{l}\text { FGFR4-5'-299 } \\
\text { FGFR4-3'-580 }\end{array}$ & $\begin{array}{l}\text { TGTCTTGTGGAGAACTCTCTGGG } \\
\text { CACCTCCACCTCTGAGCTATTGA }\end{array}$ & $282 \mathrm{bp}$ \\
\hline $\begin{array}{l}\text { insulinR-5'-1029 } \\
\text { insulinR-3'-1286 }\end{array}$ & $\begin{array}{l}\text { TTCATTCAGGAAGACCTTCGA } \\
\text { AGGCCAGAGATGACAAGTGA }\end{array}$ & $\begin{array}{l}273 \text { bp (exon } 11 \text { present) } \\
237 \text { bp (exon } 11 \text { absent) }\end{array}$ \\
\hline $\begin{array}{l}\text { IGF1R-5'-680 } \\
\text { IGF1R-3'-1024 }\end{array}$ & $\begin{array}{l}\text { AGAAAATGTGCCCAAGTGTGTGT } \\
\text { GGCCTTCACAGGGGATACAGTAC }\end{array}$ & $347 \mathrm{bp}$ \\
\hline $\begin{array}{l}\text { Ptk3-5'-420 } \\
\text { Ptk3-3'-799 }\end{array}$ & $\begin{array}{l}\text { TCCCCAAAGAAGAGGAGTACCTG } \\
\text { CTCAGATAATTGCATGGTCTGCC }\end{array}$ & $382 \mathrm{bp}$ \\
\hline $\begin{array}{l}\text { Sky-5'-398 } \\
\text { Sky-3'-693 }\end{array}$ & $\begin{array}{l}\text { GTTGAAGGTGTGCCATTCTTCAC } \\
\text { ACTGTGATGTTGAAAGGAGCTGC }\end{array}$ & $298 \mathrm{bp}$ \\
\hline
\end{tabular}

sion of several of them by polymerase chain reaction (PCR) using specific primers.

\section{Materials and methods}

Embryo harvesting and dissection. Pregnant Wistar female rats were purchased from Janvier breeding centre (Le Genet, France). The morning of the discovery of the vaginal plug was designed as embryonic day 0 (E0). Pregnant female rats were killed by cervical dislocation on embryonic day 13 (E13) of gestation and embryonic pancreata were harvested and dissected as described previously [9]. In some experiments, E13 pancreatic tissues highly enriched in epithelium or in mesenchyme were prepared [6].

Culture conditions for INS-1 cells. INS-1 cells which derive from a rat insulinoma [10] were grown in RPMI 1640 supplemented with 100 units $/ \mathrm{ml}$ penicillin, $100 \mu \mathrm{g} / \mathrm{ml}$ streptomycin, $10 \%$ fetal calf serum, $1 \mathrm{mmol} / \mathrm{l}$ sodium pyruvate, $10 \mathrm{mmol} / \mathrm{l}$ N-2-hydroxyethylpiperazine-N-2 ethanesulphonic acid (HE$\mathrm{PES}$ ), and $50 \mu \mathrm{mol} / \mathrm{l} 2$-mercaptoethanol as described previously $[11,12]$. Cultures were maintained at $37^{\circ} \mathrm{C}$ in a humidified atmosphere of $95 \%$ air and $5 \% \mathrm{CO}_{2}$.

RNA extraction. Total RNAs from adult rat brain and kidney, from E13 pancreata, from E13 pancreatic epithelium or mesenchyme or from INS-1 cells were extracted by the guanidium isothiocyanate method [13]. Briefly, pancreata were homogenized in $4 \mathrm{~mol} / \mathrm{l}$ guanidium thiocyanate solution, submitted to a phenol extraction and precipitated twice with 2-propanol. The integrity of RNA was verified by gel electrophoresis.
Reverse transcription (RT)-PCR amplification of protein-tyrosine kinases-related sequences. Total RNAs from E13 pancreas, E13 pancreatic epithelium or mesenchyme were first treated for $30 \mathrm{~min}$ at $37^{\circ} \mathrm{C}$ with RNase-free DNase (Gibco Brl, Cergy, Pontoise, France). The synthesis of the first-strand cDNA was done for $60 \mathrm{~min}$ at $37^{\circ} \mathrm{C}$ using a random hexamer. The reaction was done with ( + RT) or without (-RT) of Superscript II reverse trancriptase (Gibco Brl). PCR was done on equal amounts of cDNAs using $1 \mu \mathrm{g}$ of each degenerate oligonucleotide encoding consensus amino acid sequences within subdomains VIb and IX of the catalytic domains of protein tyrosine kinases as described previously [8]. The PCR primers are derived from the conserved motifs : H R D L A A/T R and D V W S Y/F G I/V. The upstream primer was chosen to exclude members of the src family of cytoplasmic tyrosine kinases [14]. The respective sequences of the $5^{\prime}$ (sens) and $3^{\prime}$ (antisens) primers were :

\section{TK 5 ':5 ' GA(C/T) CGN GA(C/T) (C/T)TN GCN (A/G)CN AG $3^{\prime}$ \\ TK 3 ':5' CT(A/G) CAN ACC (A/T)(G/C)(A/G) A(A/T) $(\mathrm{A} / \mathrm{G}) \mathrm{CCN}(\mathrm{C} / \mathrm{T}) \mathrm{AG} 3^{\prime}$}

$\mathrm{N}$ denotes all 4 deoxynucleotides. We carried out 35 cycles of amplification on a thermal cycler as follows : $94^{\circ} \mathrm{C}$ for $1 \mathrm{~min}$ (once), $94^{\circ} \mathrm{C}$ for $20 \mathrm{~s}, 37^{\circ} \mathrm{C}$ for $5 \mathrm{~min}$ and $65^{\circ} \mathrm{C}$ for $5 \mathrm{~min}(35$ cycles) and $65^{\circ} \mathrm{C}$ for $10 \mathrm{~min}$ (once). The resulting 200-220 bp PCR products were subcloned into the PCR II vector using TA cloning kit (Invitrogen, NV Leek, The Netherlands) and the transformation was done with INV $\alpha F^{\prime}$ competent cells provided by the TA cloning kit. Miniprep plasmid DNA was prepared from individual clones and sequencing was carried out 


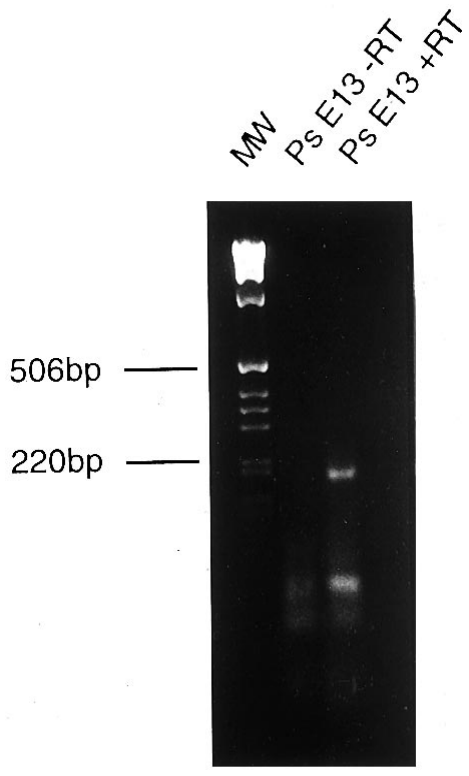

Fig. 1. PCR amplification using degenerated oligonucleotides corresponding to conserved regions in the catalytic domain of protein tyrosine kinases. Ethidium bromide staining of a $2 \%$ agarose gel containing PCR products of reverse-transcribed total RNA from E13 rat pancreata in the presence $(+\mathrm{RT})$ or in the absence $(-\mathrm{RT})$ of reverse trancriptase

Table 2. Protein tyrosine kinases amplified from E13 pancreas

\begin{tabular}{|c|c|c|c|c|}
\hline & Family & $\begin{array}{l}\text { Protein } \\
\text { tyrosine } \\
\text { kinase }\end{array}$ & Ligands & $\begin{array}{l}\text { Incidence } \\
\text { in E13 } \\
\text { rudiment }\end{array}$ \\
\hline \multirow[t]{14}{*}{$\begin{array}{l}\text { Receptor } \\
\text { tyrosine } \\
\text { kinases }\end{array}$} & \multirow[t]{6}{*}{ PDGFR } & PDGFR $\alpha$ & $\begin{array}{l}\text { PDGF-AA } \\
\text { PDGF-BB } \\
\text { PDGF-AB }\end{array}$ & 9 \\
\hline & & $\operatorname{PDGFR} \beta$ & PDGF-BB & 9 \\
\hline & & CSF1R & CSF1 & 3 \\
\hline & & Flk1 & VEGF & 1 \\
\hline & & FLT1 & VEGF & 6 \\
\hline & & FLT4 & VEGF C & 1 \\
\hline & EGFR & erbB2 & & 1 \\
\hline & \multirow[t]{2}{*}{ FGFR } & FGFR1 & FGF1/FGF2 & 9 \\
\hline & & FGFR2 IIIb & KGF & 1 \\
\hline & HGFR & MET & HGF & 3 \\
\hline & INSR & $\begin{array}{l}\text { insulin R } \\
\text { IGF1R }\end{array}$ & $\begin{array}{l}\text { insulin } \\
\text { IGF1 }\end{array}$ & $\begin{array}{r}1 \\
20\end{array}$ \\
\hline & EPH & $\begin{array}{l}\text { EphR } \\
\text { Eck } \\
\text { Ehk3 } \\
\text { Mek4 } \\
\text { Sek3 } \\
\text { Sek4 }\end{array}$ & $\begin{array}{l}\text { ephrinA } \\
\text { A } \\
\text { A } \\
\text { A } \\
\text { ephrinB } \\
\text { B }\end{array}$ & $\begin{array}{l}1 \\
1 \\
2 \\
2 \\
1 \\
4\end{array}$ \\
\hline & AXL & Sky (Tyro3) & gas6 & 2 \\
\hline & DDR & $\begin{array}{l}\text { Ptk3 (TrkE) } \\
\text { Tyro10 }\end{array}$ & NGF & $\begin{array}{l}1 \\
1\end{array}$ \\
\hline \multirow{5}{*}{$\begin{array}{l}\text { Cytoplasmic } \\
\text { protein } \\
\text { tyrosine } \\
\text { kinases }\end{array}$} & & abl & & 7 \\
\hline & & erk & & 1 \\
\hline & & Jak3 & & 1 \\
\hline & & Csk & & 2 \\
\hline & & Flk & & 2 \\
\hline \multicolumn{4}{|c|}{ Total number of PTKs analysed } & 92 \\
\hline
\end{tabular}

by the dideoxy chain-termination method using either fmol DNA sequencing system kit (Promega, Madison, USA) or ABI 377 DNA sequencer and ABI PRISM Dye Terminator Cycle Sequencing Core Kit with AmpliTaq DNA Polymerase, FS (Perkin Elmer, Courtaboeuf, France). Blast alghorithm was used to scan data bases for DNA homologies.

RT-PCR profile of expression of specific receptor tyrosine kinases. The expression of some receptor tyrosine kinases identified using degenerated primers was further studied in E13 whole pancreas, adult kidney, adult brain and INS-1 cells by RT-PCR using specific primers described in Table 1. Reverse transcription was done as described above. Equal amounts of cDNAs, based on cyclophilin amplification, were used for the different reactions using $100 \mathrm{ng}$ of each primer. Amplification variables were : $94^{\circ} \mathrm{C}$ for $5 \mathrm{~min}$ (once), $94^{\circ} \mathrm{C}$ for $1 \mathrm{~min}, 56^{\circ} \mathrm{C}$ for $1 \mathrm{~min}$ and $72^{\circ} \mathrm{C}$ for $2 \mathrm{~min}$ ( 35 cycles). PCR products were analysed on a $2 \%$ agarose gel or on a $5 \%$ acrylamide gel. Each PCR was done at least twice.

\section{Results}

Screen for receptor tyrosine kinases expressed in E13 pancreatic rudiment. To identify receptor tyrosine kinases expressed in E13 pancreas, PCR was performed at low stringency on cDNA prepared from E13 rat pancreas using degenerated oligonucleotides corresponding to 2 conserved regions of the kinase domain shared by protein tyrosine kinases. As shown in Figure 1, a PCR product of the expected size (200-220 bp) was amplified from cDNA prepared from E13 pancreas. No such amplification was obtained when the PCR was done on cDNA prepared in the absence of reverse transcriptase, showing the absence of DNA contamination. PCR products were next subcloned and sequenced. A total of 97 clones from E13 pancreata were analysed. $95 \%$ of the clones corresponded to protein tyrosine kinases and among them, $85 \%$ to receptor tyrosine kinases. Non receptors tyrosine kinase included members of the abl, erk, Jak3, csk, and Flt. Abl was the non receptor tyrosine kinase which was found at the highest frequency (Table 2).

A total of 20 different receptor tyrosine kinases sequences were identified in E13 pancreata, which were classified in 8 subfamilies of receptor tyrosine kinases: platelet derived growth factor receptor (PDGFR), epidermal growth factor receptor (EGFR), fibroblast growth factor receptor (FGFR), insulin receptor (INSR), hepatocyte growth factor receptor (HGFR), EPH, AXL and DDR. The distribution of the different receptor tyrosine kinases is presented in Table 2 and the number of times each receptor tyrosine kinase was identified is also given. In the E13 pancreas, some receptor tyrosine kinases were found at high frequency: insulin-like growth factor receptor (IGF1R) was identified 20 times; PDGFR $\alpha$ and $\beta$ were identified 9 times each. Other receptors such as Flk1, FLT4 or the insulin receptor were amplified only once. 
Table 3. Protein tyrosine kinases amplified from E13 pancreatic epithelium and from E13 pancreatic mesenchyme

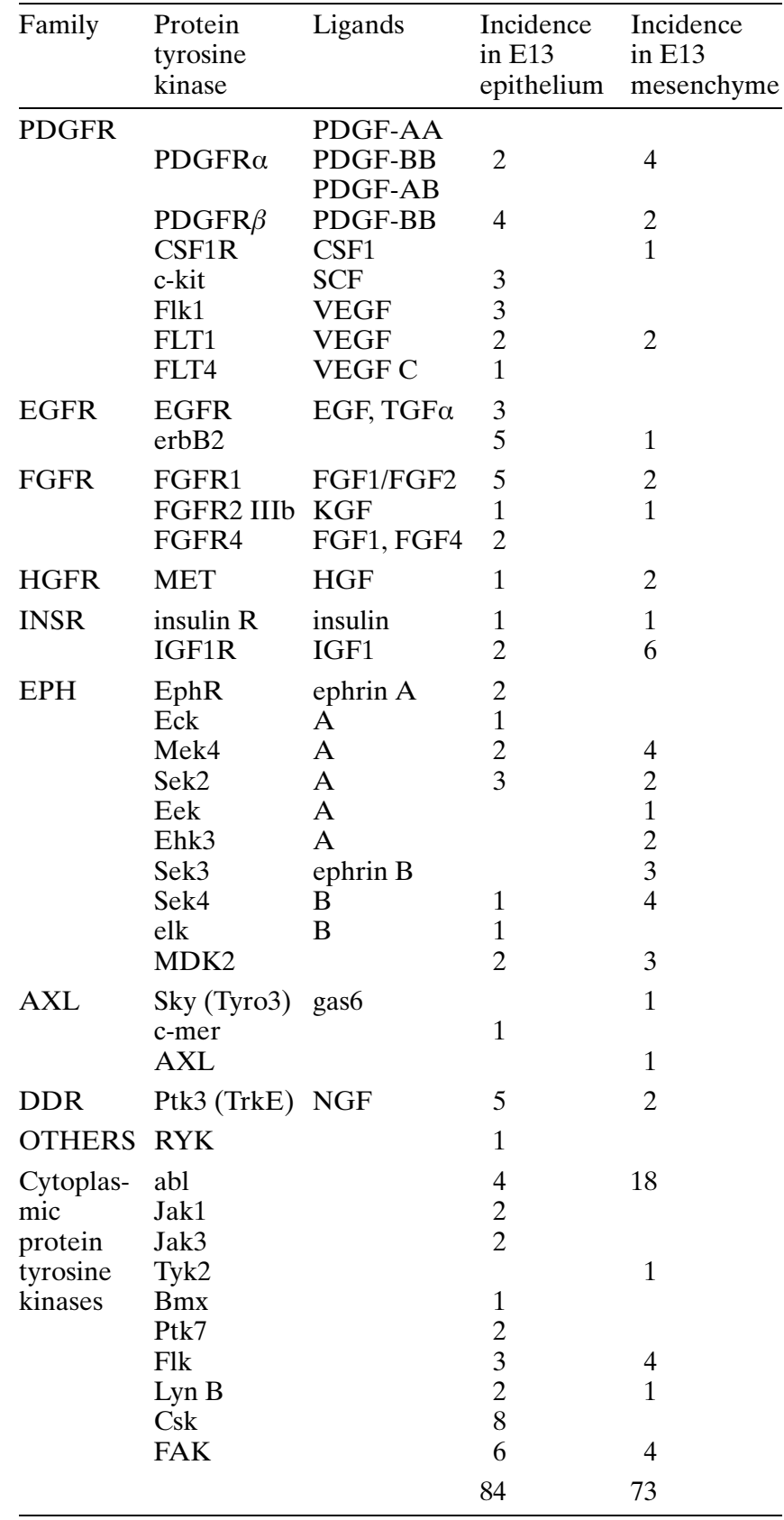

Expression of protein tyrosine kinases $m R N A$ in tissue enriched in E13 pancreatic epithelium or E13 pancreatic mesenchyme. Next we did PCR on cDNA prepared from tissues enriched in epithelium or mesenchyme derived from E13 pancreas. A total of 157 PCR products subclones with similarities to protein tyrosine kinases were analysed. In the mesenchyme, abl was the cytoplasmic tyrosine kinase which was found at the highest frequency. Focal adhesion kinase (FAK) and JAK family members were the cytoplasmic tyrosine kinase found at the highest frequency in the epithelium. JAK family members (JAK1-3) were never amplified from the mesenchymal fraction (Table 3).

The profile of receptor tyrosine kinases found in RNA prepared from fractions enriched in epithelium or in mesenchyme was also studied. Some receptors were found predominantly in the epithelium fraction (Table 3). This was the case for c-Kit, EGFR, ErbB2, FGFR4, Ptk3. Some others were found mainly in the mesenchymal fraction. This was the case for IGF1R, Sek3.

Further confirmation of receptor tyrosine kinases expression in E13 pancreas. To further confirm the expression of specific receptor tyrosine kinases in pancreatic rudiment at stage E13, PCR was done with specific primers. The primers were choosen in the extracellular domains of the different receptors. We specifically focused on receptors of PDGFR, EGFR, FGFR, INSR, AXL and DDR subfamilies. PCR products of the expected sizes were amplified from E13 pancreata for all the receptor tyrosine kinases found previously using degenerated primers. This is the case for PDGFR family members (PDGFR $\alpha$ and $\beta$, FLT1 and c-Kit) (Fig.2), EGFR family members (EGFR and erbB2), FGFR family members (FGFR1, 2b, and 4), DDR family member (Ptk-3), AXL family member (Sky) (Fig. 2) and INSR family members (INSR and IGF1R) (Fig. 2). Their sequences were found to be identical to the expected sequences. No signal was detected from samples processed in the absence of reverse transcriptase. These results further confirm the expression of receptor tyrosine kinases (PDGFR $\alpha$ and $\beta$, FLT1, c-Kit, EGFR, erbB2, FGFR1, FGFR2 b, FGFR4, Ptk-3, Sky, insulinR and IGF1R) in E13 pancreatic rudiments.

To compare the profile of expression of receptor tyrosine kinases found in E13 pancreata to the ones found in other tissues, PCR were also done using specific primers on cDNAs prepared from adult rat kidney, adult rat brain and INS-1 cells.

The levels of PDGFR $\alpha$ and PDGFR $\beta$ were found to be higher in the E13 pancreas, when compared with the kidney or INS-1 cells (Fig. 2). In INS-1 cells for example, PDGFR $\alpha$ expression was very low and PDGFR $\beta$ expression was under the limit of detection (Fig. 2). FLT1 was also amplified from pancreatic rudiments, but not from INS-1 cells. c-kit could be amplified from all three sources tested (E13 pancreas, kidney, INS-1 cells).

In the EGFR family, EGFR could be amplified from cDNAs prepared from INS-1 cells, E13 pancreata and kidney. On the other hand, ErbB2, which was amplified from cDNA prepared from pancreatic rudiments, could be poorly amplified from cDNA prepared from kidney, and could not be amplified from cDNA prepared from INS-1 cells (Fig. 2).

In the FGFR family, although FGFR1 and FGFR4 could be amplified from all three cDNA sources test- 

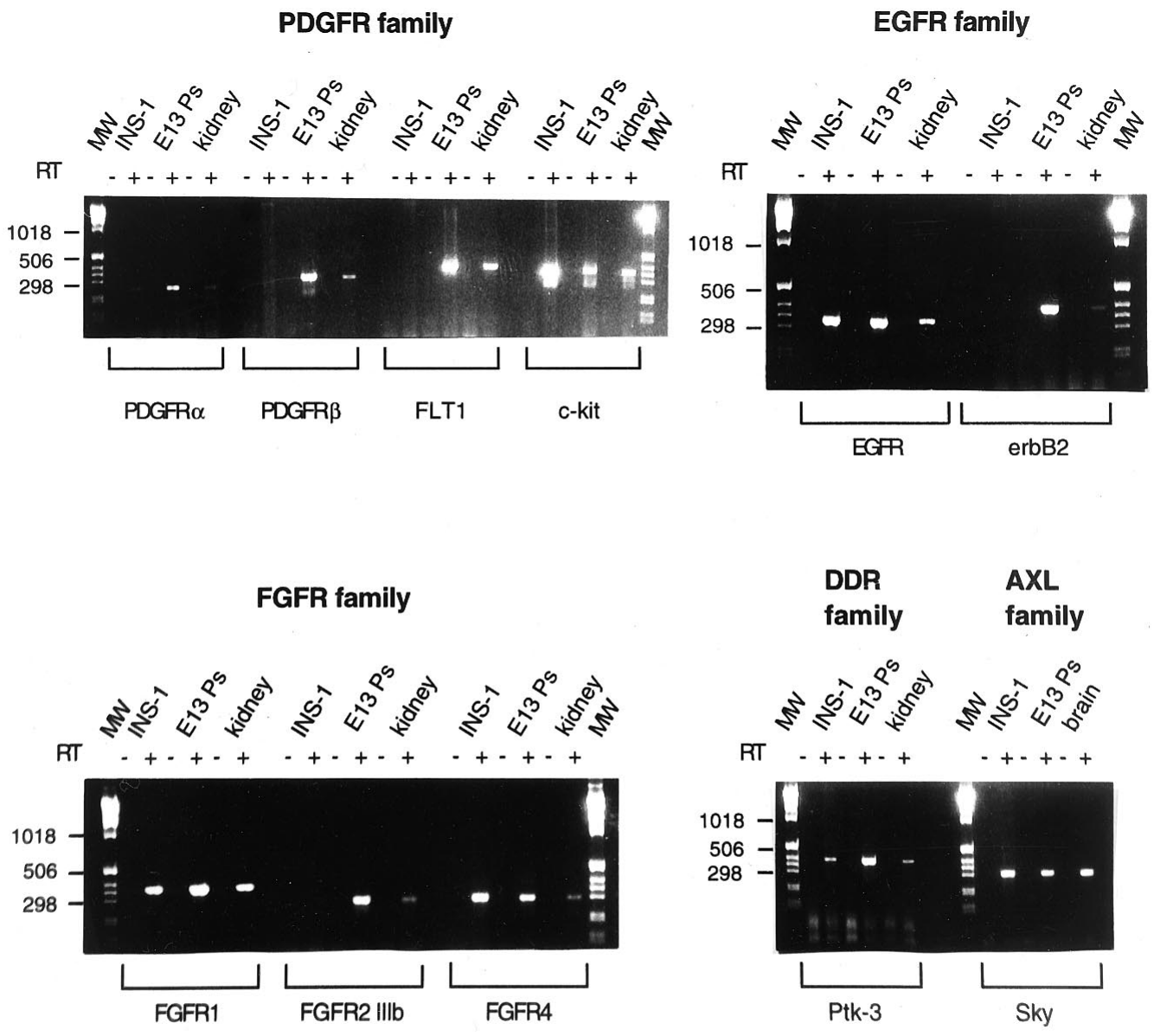

Fig. 2. PCR analysis of tyrosine kinase receptors expressed in E13 pancreas: comparison with their pattern of expression in the kidney, in the brain and in INS-1 cells. RNA was prepared from the different tissues. Reverse transcriptase was done on RNA in the presence $(+)$ or in the absence $(-)$ of reverse transcriptase. PCR were next performed on equal amounts of cDNAs using specific primers. The PCR products were loaded on a $2 \%$ agarose gel

ed, FGFR2b, which could be amplified from cDNA prepared from E13 pancreatic rudiments and kidney, could not be amplified from cDNA prepared from INS-1 cells (Fig. 2).

Members of the DDR and AXL families (Ptk-3 and Sky respectively), could be amplified from all three cDNA sources tested (Fig. 2).

Members of the INSR family (IGF1R and INSR) were also amplified from all three cDNA sources tested. Note that IGF1R was found to be highly expressed in cDNA prepared from INS-1 cells and E13 pancreata when compared with kidney (Fig. 3). Insulin receptors could also be amplified from all 4 cDNA sources tested. Finally, it is known that insulin receptor mRNA contains an exon (exon 11) which undergoes tissuespecific alternative splicing. [15]. We thus used primers spanning exon 11 to define whether exon 11 was spliced in pancreatic tissue. As described previously [15], in the kidney, a product of $273 \mathrm{bp}$ corresponding

to the isoform with exon 11 was the predominant insulin receptor DNA amplification product in the kidney but in the brain, the size of the predominant insulin receptor DNA amplification product was $237 \mathrm{bp}$, lacking exon 11 (Fig. 3). We showed here that the amplification product from INS-1 cells and E13 rat pancreas was identical to the one amplified from rat brain.

\section{Discussion}

It is well established that the development of the pancreas depends on interactions between the pancreatic epithelium and the surrounding mesenchyme [5]. As for other organs, some of these interactions are mediated by soluble factors [5, 6]. In different tissues, these soluble factors are frequently ligands for tyrosine kinase receptors [16]. We screened for tyrosine kinase receptors expressed during pancreatic development. As a starting material we used cDNA prepared from E13 rat pancreata. This time point was chosen because it is when the pancreas develops actively. For example, at this stage, the protein content of the pancreas doubles every day [4].

To characterize receptor tyrosine kinase expressed in the embryonic pancreas, we did RT-PCR using degenerated primers corresponding to conserved subdomains VIb and IX of the catalytic domain of pro- 

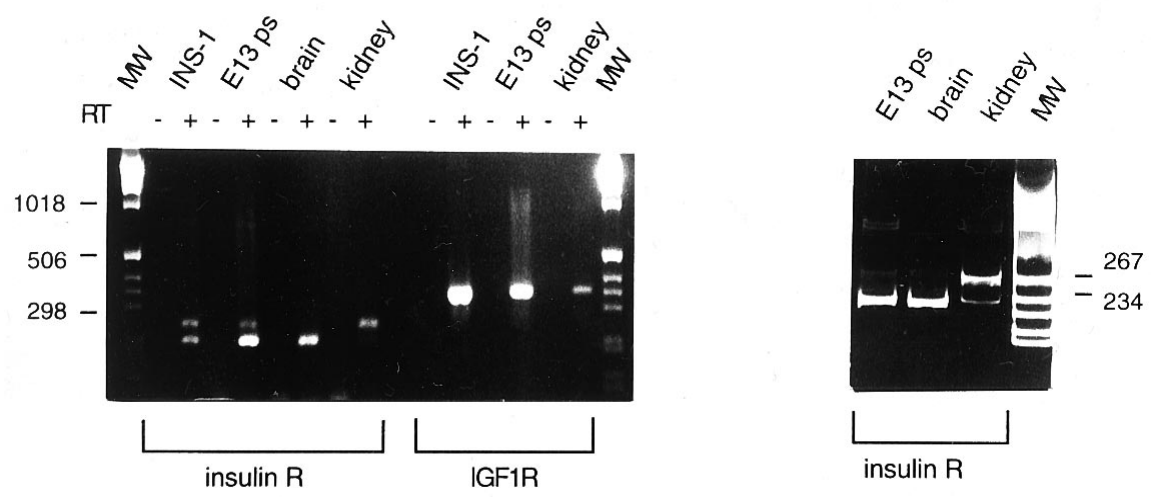

Fig. 3. PCR analysis of insulin receptor family members expressed in E13 pancreas, in the kidney, in the brain and in INS- 1 cells. The PCR products were loaded on a $2 \%$ agarose gel (left panel), or on a $5 \%$ acrylamide gel (right panel)

tein tyrosine kinases [17]. This strategy, first described by Wilks [8], has been used to characterize protein tyrosine kinases expressed in the nervous system [14], in hippocampal neurons [18], in haematopoietic cells [19], in the prostate [20] and in pancreatic islets [21]. For example, in the nervous system, 27 different protein tyrosine kinases, including 22 receptor tyrosine kinases, have been cloned [14]. In a prostate carcinoma, nearly 40 different protein tyrosine kinases, including 11 receptor tyrosine kinases, have been cloned [20]. Such a strategy has also been used previously on fetal pancreatic tissue [21] but on a very small scale ( 5 different protein tyrosine kinases were cloned) when compared with our present study in which we cloned 41 different protein tyrosine kinases from E13 rat pancreas. It is clear, however, that even in our study, all protein tyrosine kinases expressed in the E13 pancreas have not been cloned using this strategy. For example, we have not cloned Trk-A from E13 rat pancreas using degenerated primers, but Trk-A can be amplified when non-degenerated primers are used [22]. Abundance of receptor transcript clearly represents a limiting step in the screening, and protein tyrosine kinases weakly expressed have less chance of being cloned.

In our study, both PDGFR $\alpha$ and $\beta$ were amplified from E13 pancreas. There is little information relating to the implication of PDGF in pancreatic development including only one report showing that in fetal rat islets of Langerhans in tissue culture, PDGF stimulates islet cell DNA replication, suggesting that it is of importance for fetal islet development [23]. The expression of PDGFR was, however, not followed. In other tissues, PDGF and its receptors have been implicated in development. For example, during lung development, a model of epithelio-mesenchymal interactions, PDGF-AA and PDGF-BB have been shown to influence cell proliferation and branching. These effects were shown to be mediated by PDGFR $\alpha$ and $\beta$ receptors, expressed in the lung in development $[24,25]$. The cell types expressing PDGFRs in the development of the pancreas have now to be defined. In our present study, PDGFR $\alpha$ and $\beta$ have been amplified both from the epithelium and from the mesenchyme, suggesting that both tissues express the receptors.

Furthermore, c-kit, the receptor for stem cell factor, was amplified from E13 pancreatic epithelium and from INS-1 cells. The c-kit/stem cell factor transduction pathway is known to be implicated in cell migration, proliferation and survival of melanoblasts, haematopoietic progenitors and primordial germ cells [26]. The expression of c-kit had not been shown previously in the embryonic pancreas. There is one report of the detection of c-kit-immunoreactivity in the ducts adjacent to the islets during late fetal life (E21) [27]. Recently, in an attempt to define new kitdependent lineages, the c-kit gene was inactivated and replaced by the Escherichia coli lacZ gene [28]. It was found that at E12.5, few epithelial collector tubes were $\beta$-gal positive but at birth, some collector tubes and most cells of the islets of Langerhans were $\beta$-gal positive, strongly suggesting that c-kit is expressed by pancreatic epithelial cells. Our results further confirm the expression of c-kit in pancreatic epithelial cells. The role of c-kit in pancreatic development has now to be studied. One working hypothesis would be that c-kit/stem cell factor could be implicated in cell migration within the pancreas. This hypothesis is based firstly on c-kit/stem cell factor being implicated in cell migration in other cell types, such as melanoblasts [26] and secondly on cell migration of endocrine cells within the pancreatic extracellular matrix representing a key step in islet morphogenesis $[29,30]$.

In the embryonic pancreas, we detected 2 members of the EGFR family EGFR and ErbB2. Both EGFR and ErbB2 were found enriched in the epithelium when compared to the mesenchyme. EGFR but not ErbB2 was also amplified from INS-1 cells, which 
derived from a rat insulinoma. EGFR is known to bind EGF, but also transforming growth factor alpha, which has been implicated in pancreatic development [31-33]. EGFR and ErbB2 have also been found to be implicated in betacellulin and heparin binding epidermal growth factor-like growth factor (HB-EGF) signal transduction [34], 2 factors thought to be implicated in pancreatic development. It has been shown that betacellulin, was able to convert amylase-secreting pancreatic AR42J cells into insulin-secreting cells in the presence of activin [35]. It has also been proposed that HB-EGF may function as a mediator of PDX-1 [36]. Recently, we have described an in vitro culture system where the effect of soluble factor on pancreatic development can be tested [6]. The effect of EGF, transforming growth factor alpha, betacellulin, HB-EGF should now be tested in this experimental system.

Another interesting point concerns the expression of FGFR in the embryonic pancreas. Recently, we demonstrated that FGF2 was a mitogen for pancreatic embryonic epithelial cells [37], and in this study, the expression of FGFR1, FGFR2 b and FGFR4 was detected in E13 pancreata. Although both FGFR1 and FGFR4 expression was also found in INS-1 cells, FGFR2b was not amplified from such a pancreatic endocrine cell line suggesting that FGFR2b could represent a marker of primitive epithelial pancreatic cells. Some arguments fit with this hypothesis. In other tissues, such as lung for example, which are composed of an epithelium and a mesenchyme, FGFR2 b is found to be expressed by embryonic epithelial cells $[38,39]$. Thus, in the pancreas, FGF7, the ligand of FGFR2b could be expressed by mesenchymal cells and act on epithelial cell to control their proliferation or their differentiation or both.

In conclusion, we have been able to define a range of tyrosine kinase receptors which are expressed in the E13 rat pancreas.

Acknowledgements. S. Mahé is acknowledged for her technical assistance and F. Miralles for the epithelio-mesenchymal separation. Automatic sequencing was performed in the laboratory of Dr P. Froguel, CNRS EP10. Members of CNRS EP10 are acknowledged. This work was supported by grants from the Juvenile Diabetes Foundation International and by the European Union. S. LeBras was supported by "l'Association d'Aide aux Jeunes Diabétiques".

\section{References}

1. Minno P, King R (1994) Epithelial-mesenchymal interactions in lung development. Ann Rev Physiol 56: 13-45

2. Vainio S, Müller U (1997) Inductive tissue interactions, cell signaling, and the control of kidney organogenesis. Cell 90: 975-978

3. Yang Y, Spitzer E, Meyer D et al. (1995) Sequential requirement of hepatocyte growth factor and neuregulin in the morphogenesis and differentiation of the mammary gland. J Cell Biol 131: 215-226
4. Pictet R, Rutter WJ (1972) Development of the embryonic pancreas. In: Steiner DF, Freinkel N (eds) Handbook of Physiology, American Physiological Society, Williams and Wilks, Washington, pp 25-66

5. Golosow N, Grobstein C (1962) Epitheliomesenchymal interaction in pancreatic morphogenesis. Dev Biol 4: 242255

6. Miralles F, Czernichow P, Scharfmann R (1998) Follistatin regulates the relative proportions of endocrine versus exocrine tissue during pancreatic development. Development 125: $1017-1024$

7. Ronzio R, Rutter W (1973) Effect of a partially purified factor from chick embryos on macromolecular synthesis of embryonic pancreatic epithelia. Dev Biol 30: 307-320

8. Wilks A (1989) Two putative protein-tyrosine kinases identified by application of the polymerase chain reaction. Proc Natl Acad Sci USA 86: 1603-1607

9. Gittes G, Galante P (1993) A culture system for the study of pancreatic organogenesis. J Tissue Cult Methods 15: 23-28

10. Asfari M, Janjic D, Meda P, Li G, Halban P, Wolheim K (1992) Establishement of 2-mercaptoethanol-dependent differentiated insulin secreting cell lines. Endocrinology. 130: $167-178$

11. Scharfmann R, Tazi A, Polak M, Kanaka C, Czernichow P (1993) Expression of functional nerve growth factor receptors in pancreatic beta cell lines and fetal rat islets in primary culture. Diabetes 42: 1829-1836

12. Scharfmann R, Atouf F, Tazi A, Czernichow P (1994) Growth hormone and prolactin regulate the expression of Nerve growth factor receptors in INS-1 cells. Endocrinology 134: 2321-2328

13. Chomczynski P, Sacchi N (1987) Single-step method of RNA isolation by acid guanidium thiocyanate-phenolchloroform extraction. Anal Biochem 162: 156-159

14. Lai C, Lemke G (1991) An extended family of protein-tyrosine kinase genes differentially expressed in the vertebrate nervous system. Neuron 6: 691-704

15. Goldstein B, Dudley A (1990) The rat insulin receptor: primary structure and conservation of tissue-specific alternative messenger RNA splicing. Mol Endocrinol 4: 235-244

16. Schlessinger J, Ullrich A (1992) Growth factor signaling by receptor tyrosine kinases. Neuron 9: 383-391

17. Hanks S, Quinn A, Hunter T (1988) The protein kinase family: conserved features and deduced philogeny of the catalytic domains. Science 241: 42-52

18. Sanchez M, Tapley P, Saini S, He B, Pulido D, Barbacid M (1994) Multiple tyrosine protein kinases in rat hippocampal neurons: isolation of Ptk-3, a receptor expressed in proliferative zones of the developing brain. Proc Natl Acad Sci USA 91: 1819-1823

19. Matthews W, Jordan C, Gavin M, Jenkins N, Copeland N, Lemischka I (1991) A receptor tyrosine kinase cDNA isolated from a population of enriched primitive hematopoietic cells and exhibiting close genetic linkage to c-kit. Proc Natl Acad Sci USA 88: 9026-9030

20. Robinson D, He F, Pretlow T, Kung H-J (1996) A tyrosine kinase profile of prostate carcinoma. Proc Natl Acad Sci USA 93: 5958-5962

21. Oberg C, Waltenberger J, Claesson-Welsh L, Welsh M (1994) Expression of protein tyrosine kinases in islet cells: possible role of Flk-1 receptor for $\beta$-cell maturation from duct cells. Growth Factors 10: 115-126

22. Miralles F, Philippe P, Czernichow P, Scharfmann R (1998) Expression of Nerve Growth Factor and its high affinity receptor Trk-A in the rat pancreas during embryonic and fetal life. J Endocrinol 156: 431-439 
23. Swenne I, Heldin C-H, Hill D, Hellerstrom C (1988) Effects of platelet-derived growth factor and somatomedin$\mathrm{C} /$ insulin-like growth factor I on the deoxyribonucleic acid replication of fetal rat islets of Langerhans in tissue culture. Endocrinology 122: 214-218

24. Souza P, Sedlackova L, Kuliszewski M et al. (1994) Antisense oligonucleotides targeting PDGF-B mRNA inhibit cell proliferation during embryonic rat lung development. Development 120: 2163-2173

25. Souza P, Kuliszewski M, Wang J, Tseu I, Tanswell K, Post M (1995) PDGF-AA and its receptor influence early lung branching via an epithelial-mesenchymal interaction. Development 121: 2559-2567

26. Galli S, Zsebo K, Geissler E (1994) The kit ligand, Stem Cell Factor. Adv Immunol 55: 1-96

27. Oberg-Welsh C, Welsh M (1996) Effect of certain growth factors on in vitro maturation of rat fetal islet-like structures. Pancreas 12: 334-339

28. Bernex F, DeSepulveda P, Kress C, Elbaz C, Delouis C, Bernex J-J (1996) Spatial and temporal patterns of c-kit-expressing cells in WlacZ/ + and WlacZ/WlacZ mouse embryos. Development 122: 3023-3033

29. Deltour L, Leduque P, Paldi A, Ripoche M, Dubois P, Jami J (1991) Polyclonal origin of pancreatic islets in aggregation mouse chimaeras. Development 112: 1115-1121

30. Dahl U, Sjodin A, Semb H (1996) Cadherins regulate aggregation of pancreatic $\beta$-cells in vivo. Development 122 : 2895-2902

31. Wang T, Bonner-Weir S, Oates P, Chulack M, Simon B (1993) Pancreatic gastrin stimulates islet differentiation of transforming growth factor alpha-induced ductular precursor cells. J Clin Invest 92: 1349-1356
32. Sandgren E, Luettke N, Palmiter R, Brinster R, Lee D (1990) Overexpression of TGFa in transgenic mice: induction of epithelial hyperplasia, pancreatic metaplasia and carcinoma of the breast. Cell 61: 1121-1135

33. Jhappan C, Stahle C, Arkins R, Fausto N, Smith G, Merlino $G$ (1990) TGFa overexpression in transgenic mice induces liver neoplasia and abnormal development of the mammary gland and pancreas. Cell 61: 1137-1146

34. Beerli R, Hynes N (1996) Epidermal growth factor-related peptides activate distinct subsets of ErbB receptors and differ in their biological activities. J Biol Chem 271: 6071-6076

35. Mashima H, Ohnishi H, Wakabayashi K et al. (1996) Betacellulin and activin A coordinately convert amylase-secreting pancreatic AR42 J into insulin-secreting cells. J Clin Invest 97: 1647-1654

36. Kaneto H, Miyagawa J-I, Kajimoto Y et al. (1997) Expression of heparin-binding epidermal growth factor-like growth factor during pancreas development. J Biol Chem 46: 29137-29143

37. LeBras S, Miralles F, Basmaciogullari A, Czernichow P, Scharfmann R (1998) Fibroblast Growth Factor 2 promotes pancreatic epithelial cell proliferation via functional Fibroblast Growth Factor receptors during embryonic life. Diabetes 47: 1236-1242

38. Ohmichi H, Koshimizu U, Matsumoto K (1998) Hepatocyte growth factor acts as a mesenchyme-derived morphogenic factor during fetal lung development. Development 125: 1315-1324

39. Post M, Souza P, Liu J et al. (1996) Keratinocyte growth factor and its receptor are involved in regulating early lung branching. Development 122: 3107-3115 